Vol. 15, no. 2, Dec 2021, pp. 34-62

$10.2478 /$ host-2021-0012

\title{
Making Modern Knowledge of Traditional Carpentry in China and Japan: Myth, Reality and Transmission
}

\author{
Ren Congcong 任丛丛 \\ Beijing University of Civil Engineering and Architecture, China \\ rencongcong@bucea.edu.cn
}

\begin{abstract}
Carpentry skills were among the most important elements of building practice in premodern China and Japan, and traditional carpentry skills continue in use in both countries to the present day. Although their importance has been greatly marginalised in building practice, in both countries some master carpenters have gained public recognition. This paper compares the modernisation of traditional building knowledge in China and Japan, and the fate of carpentry knowledge as the building industry and the formal discipline of architecture evolved. It distinguishes three phases in this historical trajectory: the period during the introduction of Western architecture as a discipline, when traditional knowledge was rejected or used selectively in the construction of national histories of building; the period when modern technology took over the main building industry and traditional craftsmen had to confront the realities of new technologies of production; and the period, still unfolding today, where heritage movements are promoting the recuperation and development of traditional craft knowledge. For each country, the paper traces how the nation's history of building was selectively fashioned into an orthodox narrative; explores the content of key early technical works (for China, the official handbook Yingzao fashi [Building standards] and the craftsman's manual Lu Ban jing [Carpenters' Canon], and for Japan kikujutsu [literally, "compass and ruler techniques"] books); and shows how a talented master carpenter succeeded in creating a niche for himself within the contemporary heritage culture. It concludes that differences in the cultural respect accorded to carpentry knowledge in the two countries are rooted in the contrasting status of craftsmen in the premodern era.
\end{abstract}

Keywords: craft knowledge; architecture; modernization; China; Japan 


\section{Introduction}

In August 2020, "Inside and Outside the Window: A Special Exhibition of Liang Sicheng (1901-1972) and Lin Huiyin (1904-1955)" opened at the Shenzhen Museum of Contemporary Art and Urban Planning. The couple, both trained as architects in the United States, played prominent roles in establishing modern architecture as a professional practice and academic discipline in Republican China (1912-1949), and helped found historical research into China's architectural past. Liang was the son of the influential modernising reformer Liang Qichao; Lin was both an architect and a much-admired author and poet. ${ }^{1}$ A news report on the Shenzhen exhibition stated that Liang was a master architect and Lin a "talented woman." ${ }^{2}$ The exhibition showed their struggle for the fate of China and praised the "new era" of urban planning in China which the two helped launch. ${ }^{3}$ At the same time, the Urban Architecture Biennale was about to open in Beijing. There, two huge 1:1 dougong (bracket set) models (Figure 1) were displayed as a highlight of the exhibition; the prototypes of these two dougong were from the Tang-dynasty Foguang Temple in Mount Wutai (dedicated in 857) and the Ming-dynasty Hall of Supreme Harmony in the Forbidden City (completed 1406). The dougong or bracket set was a standard component of the eaves of ancient buildings, but today, due in large part to Liang Sicheng's formulation of China's architectural history, it is singled out as a cultural symbol of ancient architectural craftsmanship.

The glorification of what was once just one routine part of the carpenter's repertory was an outcome of cultural and social practices driven by architects in the post-imperial upsurge of democracy. Formal architectural training only began in the Republican era. The first generation of professional architects, of whom Liang and Lin were representative, created a history of Chinese traditional architecture based on a periodization of building styles in accordance with then "'modern' criteria." ${ }^{\prime}$ Although aspects of their research paradigm have been criticized by

\footnotetext{
${ }^{1}$ Liang Qichao is known as "the father of modern China." Shiqiao Li, "Writing a Modern Chinese Architectural History: Liang Sicheng and Liang Qichao," Journal of Architectural Education 56, no. 1 (2002): 35-45, doi: 10.1162/104648802321019155; Wilma Fairbank, Liang and Lin: Partners in Exploring China's Architectural Past (Philadelphia, PA: University of Pennsylvania Press, 1994); Tao Zhu, "To Search High and Low: Liang Sicheng, Lin Huiyin, and China’s Architectural Historiography, 19321946," Scapegoat: Architecture, Landscape, Political Economy 3 (2012): 30; Weijie Song, "The Aesthetic versus the Political: Lin Huiyin and Modern Beijing," Chinese Literature: Essays, Articles, Reviews (CLEAR) 36 (2014): 61-94.

${ }^{2}$ In imperial China this term referred to women of learning, poets, writers or artists who were revered by their society; see Susan Mann, The Talented Women of the Zhang Family (Berkeley: University of California Press, 2007).

${ }^{3}$ See the introduction to the open ceremony of the exhibition, which was published on official website of Shenzhen Museum of Contemporary Art and Urban Planning.

${ }^{4}$ Liu argued, "In general, in the Chinese Republican era (1912-49), periodization schemes of Chinese architecture can be said to affirm nationalistic agendas, while after the formation of the People's Republic in 1949 they tended to adhereto Sino-Marxist dialectics." See Cary Y. Liu, "Between the Titans:
} 
today's academics, ${ }^{5}$ the knowledge they created, and the legends they generated, have remained influential. This in turn has had an impact on traditional craftsmanship through the development of the heritage industry. Although architects "enchanted" dougong as a cultural symbol of traditional architecture, they themselves have not devised any technological innovations for making them, nor has their admiration entailed acquiring practical knowledge from craftsmen. Instead, some traditional carpenters have seized the opportunity to make dougong into consumer artefacts. ${ }^{6}$

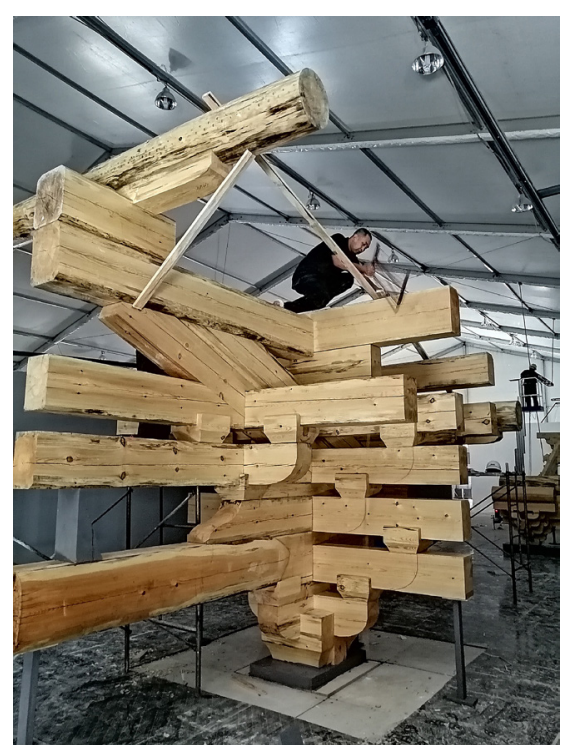

Figure 1. The 1:1 dougong model from the Tang-dynasty Foguang Temple in Mount Wutai, Beijing. Photo by the author, 2020 .

Constructions of Modernity and Tradition at the Dawn of Chinese Architectural History," in Bridges to Heaven: Essays on East Asian Art in Honor of Professor Wen C. Fong, ed. Jerome Silbergeld, Dora C.Y. Ching, Judith G. Smith and Alfreda Murck, 185-210 (Princeton: Publications of the Department of Art and Archaeology, Princeton University, 2011).

${ }^{5}$ For a critique of Liang's selection and omission of Tang-dynasty buildings, and his choice of Foguang Temple in Mount Wutai as the iconic type, see Nancy Shatzman Steinhardt, "The Tang Architectural Icon and the Politics of Chinese Architectural History," The Art Bulletin 86, no. 2 (2004): 228-54, doi: 10.1080/00043079.2004.10786192. Zhu Tao, for his part, criticises Liang and Lin for what he sees as a nationalist, patriotic slant that presupposed a law of historical development for traditional Chinese architecture, and analyses the influence of western academic thought on their ideas; Zhu Tao, Liang Sicheng he tade shidai [Liang Sicheng and His Era] (Guangxi: Guangxi Normal University Press, 2014). However, Zhu's monograph seems to have given offence to some Chinese mainland architecture historians, who published articles and reviews specifically to contradict him. See Zhu Yongchun, "Liang Sicheng zhongguo jianzhushi dui Yidong Zhongtai de chaoyue" [Liang Sicheng and His History of Chinese Architecture That Exceeds Ito Chuta's Scholarship], Jianzhu xuebao 6 (2016): 100-7; Ji Yuanzhen, "Ping Zhu Tao de xinshu- Liang Sicheng he tade shidai" [Review of Zhu Tao's Liang Sicheng and His Era], Zhuqu 5 (2016): 58-61ff.

${ }^{6}$ The so-called cultural and creative products that they have succeeded in launching on the market, in addition to handmade miniature wooden dougong, include dougong made of plastic and other materials, sold in the form of desktop calendars, educational toys or tourist souvenirs. 
In Japan as well as China, carpentry was the core of traditional building expertise. Modernisation driven by Western paradigms began with the Meiji era (1868-1912). As in China, but some years earlier, as architecture became a profession, a history of traditional Japanese architecture began to be formulated by trained architects, with early research focusing on monumental buildings such as ancient temples and shrines. ${ }^{7}$ Traditional carpenters threatened by elimination by Western architectural technology had to confront the problem of surviving in a new era. But unlike Chinese carpenters, who resigned to the triumph of mainstream architectural discourse, Japanese craftsmen were more proactive and more powerful in defending their unique selling point. ${ }^{8}$ When it comes to meeting the needs of modern society, Japanese craftsmen have shown more autonomy and initiative. The restoration and dissemination of an ancient wood-working tool, the yarigana, discussed next, provides a good example (Figure 2).

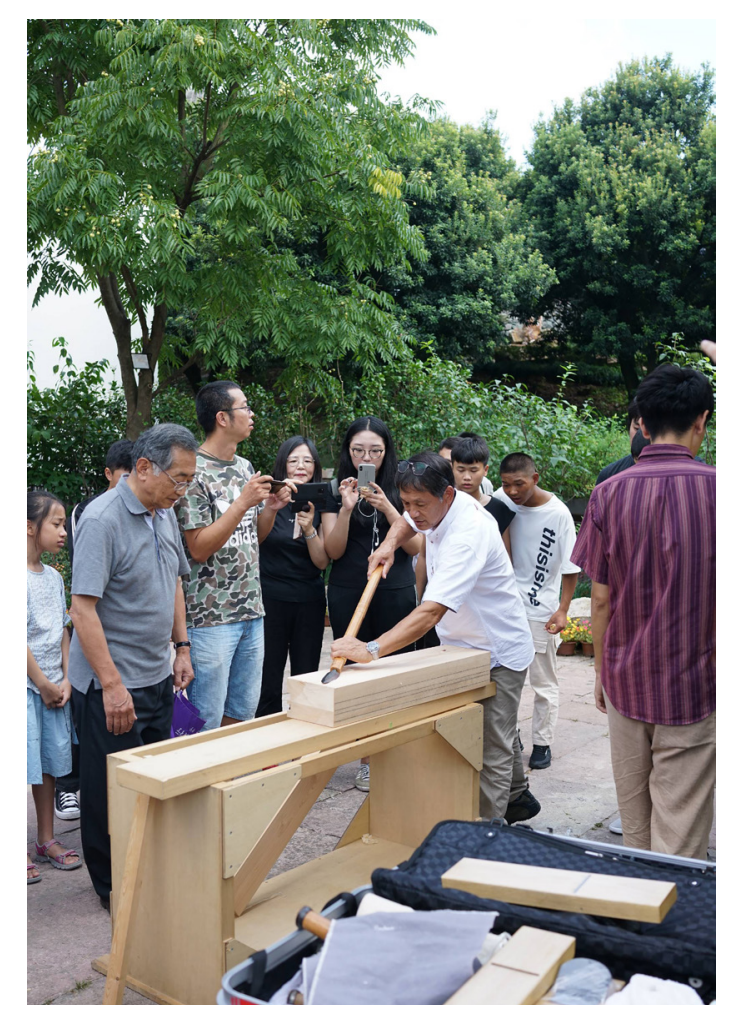

Figure 2. The performance of a Japanese carpenter using a yarigana. Ningbo, China. Photo by the author, 2019.

\footnotetext{
7 Zhu, Liang Sicheng and His Era, 15-34.

${ }^{8}$ Carpenter Nishioka, referred to later, once said, "Scholars value styles . . . It is us carpenters who built the buildings ... Scholars are just guys who study buildings built by us and record them systematically as knowledge. So, they should be our pupils." As quoted in Ki no kokoro Butsu no kokoro [The Heart of a Tree, the Heart of Buddha], 1st edition (Tokyo: Shunjusha Publishing Company, 1986), 21, in which dialogues between Nishioka and traditional Buddha statue sculptor master Hohrin Matsuhisa are recorded.
} 


\section{From “yingzao"to "jianzhu”- the establishment of modern Chinese architecture}

In 1928, Liang had just graduated from the University of Pennsylvania, Department of Architecture, and returned to China, where he joined the newly established Northeastern University in Shenyang with his wife, Lin, by proposal of his father, Liang Qichao. There he established China's first architecture programme. The usual term for building projects in imperial China had been yingzao (营造). However, the name of Liang's programme used a Chinese neologism, jianzhu( 建筑), which corresponds to the term for "architecture" commonly used in Japan. Later, Liang recruited more talent from Pennsylvania. If things had continued on that trajectory, early Chinese architecture would likely have duplicated the all-round aspect of American education. However, things changed when Japan occupied the northeast. ${ }^{9}$ In 1931, Liang had to return to Peking, where he entered the Society for the Study of Chinese Architecture with an excellent academic background for conducting research.

The Society for the Study of Chinese Architecture (hereafter referred to as SSCA) initiated by Zhu Qiqian (1872-1964) was founded in 1928 and sponsored by the China Foundation for the Promotion of Education and Culture, a special foundation established through the "Boxer Indemnity." ${ }^{10}$ Zhu was a juren ${ }^{11}$ in the late Qing Dynasty and occupied a series of important official positions from the late Qing Dynasty to the so-called Warlord era (1916-1928). In 1919 Zhu was entrusted by President Xu Shichang to attend the Peace Talks between the South and North in Shanghai as general representative of the North. While passing through Nanjing, Zhu found a manuscript of Yingzao fashi (Building standards), a work ever since considered foundational for the history of Chinese architecture, in the Jiangsu Nanjing Library. Zhu had always been fond of traditional craftsmanship and had led many construction projects, and he realised the important technical value of this book. In 1925 the book was published with the cooperation of the famous bookseller and restorer Tao Lanquan (or Tao Xiang), using the Shaoxing (1145) edition as the master copy; the colour illustrations were redrawn by the carpenter He Xingeng who served in the official construction team in Beijing in the late Qing Dynasty. ${ }^{12}$

\footnotetext{
9 See, e.g., Joanna Waley-Cohen, The Sextants of Beijing: Global Currents in Chinese History (New York: W. W. Norton \& Company, 1999), 232-7.

${ }^{10}$ See, e.g., Frank H. H. King, "The Boxer Indemnity: 'Nothing but Bad', Modern Asian Studies 40, no. 3 (2006): 663-89.

${ }^{11}$ Juren was a rank achieved by people who passed the xiangshi exam in the imperial examination system of Imperial China, also known in English as the provincial examination.

${ }^{12}$ Tao Xiang, ed., Li Mingzhong Yingzao fashi (The Yingzao fashi by Li Mingzhong [Li Jie]), 8 vols, (n.p., 1925); Else Glahn, "On the Transmission of the 'Ying-Tsao fa-shih'," T'oung Pao 61 (1975): 232-65; Shiqiao Li, "Reconstituting Chinese Building Tradition: The Yingzao Fashi in the Early Twentieth Century," Journal of the Society of Architectural Historians 62, no. 4 (2003): 470-89, doi: 10.2307/3592498. The Yingzao fashi was completed in 1100 and the first printed edition was published
} 
There are few records in Chinese traditional knowledge culture about craftsmanship, especially in the field of building. In fact, Yingzao fashi is not a technical book designed for transmission or dissemination, bu an official publication about building standards that played a considerable role in Wang's reform. ${ }^{13}$ To improve the poor and weak state of the Northern Song Dynasty, Wang Anshi (1021-1086), who as prime minister under Emperor Shenzong initiated taxation reforms, military campaigns, new imperial examinations, etc., hoped to increase the national fiscal revenue and achieve the goal of making the country rich and its military force efficient. Yingzao fashi was simply a code promulgated in connection with this reform and to save tax expenditure on construction.

The author, Li Jie (1035-1100, courtesy name Li Mingzhong), was also an official in the Northern Song Dynasty who spent three years investigating construction sites and a variety of kinds of architectural craftsmanship, especially the use of labour and materials. Under the guidance of this book, the final cost of a building with clear specifications can be inferred, and the purpose of supervision and saving was achieved. But if we compare Yingzao fashi with the knowledge base of Western architecture, such as the Ten Books on Architecture, written by Marcus Vitruvius Pollio and re-excavated and published in the fifteenth century, we see that Yingzao fash $i$ was not intended to teach architectural design or even building techniques. As Glahn pointed out, "The text was not intended to teach the principles of architecture to members of the department staff but to instruct them in managing construction accounts. After all, the craftsmen employed by the department knew perfectly well how to build." ${ }^{14}$

Zhu Qiqian was an old-style official, and was familiar with the existing building crafts, social organisation and aesthetic culture of traditional society. He was actually quite similar to $\mathrm{Li}$ Jie in status and experience. When he began his career as an official, he had opportunities to inspect construction sites in different areas and would work along with craftsmen and traders, investigate their skills and question their abilities. ${ }^{15}$ He had no academic background in Western architecture. In his "Speech to the Conference of the Society for the Study of Chinese Architecture," he pointed to the direction he felt the SSCA should take, comparing Yingzao fashi to a key: "Li's book may be made to serve as a key to open a part of the secret of history, and the history of Chinese architecture, and as that history discloses itself, we feel the need, even more than before, to gain a general view of the history of Chinese culture." ${ }^{16}$ Zhu believed that

in 1103 .

13 Else Glahn, "Chinese Building Standards in the 12th Century," Scientific American 244, no. 5 (May 1981): 162-73.

${ }^{14}$ Ibid., 169.

15 Shan Shiyuan, "Zhu Qiqian yu zhongguo yingzaoxueshe" [Zhu Qiqian and Yingzao xueshe], in Yingzaolun- ji zhuqiqian jinian wenji [Essays on construction-A festschrift for Zhu Qiqian], ed. Cui Yong, 188-90 (Tianjin: Tianjin University Press, 2009), 189.

${ }^{16}$ Zhu Qiqian, "Zhongguo yingzaoxueshe kaihui yanci”[Speech to the Conference of the Society for 
in addition to the aesthetics of buildings, the research object should also include the customs, traditions, social institutions and political and social elements that could be seen, traced and explained in architecture. He also stressed the importance of being less nationalistic, "When we speak of the study of cultural evolution, there is no place for nationalistic distinctions. The Chinese people have richly absorbed the achievements of other races, and one can see various foreign influences in all our artistic 'genres'."17

When it came to specific objects, craftsmanship should be highlighted and folklore methods employed. Zhu furthermore believed that architecture was not separable from the broader field of art. He said "The Chinese name of our society (Zhongguo yingzao xueshe, Chinese society for the study of building) does not contain the term 'architecture'(jianzhu)." The reason for this is that although Chinese architecture is our chief interest, we feared that if we called ourselves a Society for the Study of Architecture, we would too strictly limit the scope of our work and thus render us unable to carry on the investigations we plan into related fields. Thus, we include within our range material arts: painting, sculpture as used in decoration, silk, lacquer, metal work and earthen ware; and when necessary, to find explanations for our central problems, we will include non-material culture: traditions, beliefs, rituals, music and dance." ${ }^{18}$

In 1931, Liang joined the SSCA. Zhu appointed Liang director of technical studies (fashi bu) and Liu Dunzhen director of documentary studies (wenxian bu), ${ }^{19}$ handing over research to the younger generation. In addition to conducting field surveys of the relics on the ground, Liang took over the compilation of Gongbu gongcheng zuofa [Qing Dynasty Building Methods of the Ministry of Works] (1734) and studies on Yingzao fashi, which Zhu had already started. In 1937, the evening before the Marco Polo Bridge Incident that launched Japan's invasion of China, Liang and his wife discovered a Tang-dynasty temple - the Foguang Temple in Mount Wutai. ${ }^{20}$ After the outbreak of the Anti-Japanese War the couple moved from Beijing to the southwestern home front and continued the Society's work from the village of Li Zhuang in Sichuan. In 1946, after Japan's defeat, Liang returned to Tsinghua University in Beijing

the Study of Chinese Architecture], in Yingzaolun- ji zhuqiqian jinian wenji [Essays on construction-A festschrift for Zhu Qiqian], ed. Cui Yong, 12-20 (Tianjin: Tianjin University Press, 2009), 13-4.

${ }^{17}$ Ibid., $14-5$.

${ }^{18}$ Ibid., 18-20.

${ }^{19}$ See Steinhardt, "The Tang Architectural Icon," 244.

20 The exact date Liang discovered Foguang Temple was 5 July 1937. The discovery of Foguang Temple overturned Japanese scholars' assumptions that there were no surviving architectural remains in China dating back to the Tang dynasty. The discovery was published in the news just four days later, and was said to fire public patriotism (Beiping chenbao [Beiping Morning Post], September 7, 1937). The endeavour of Liang Sicheng and of his father Liang Qiqao was to promote the construction of an indigenous science of history, relying on the application of Western methods to conventional studies of such fields of history in China as architecture, archaeology, etc. See Zhao Chen, "Tianshu yu wenfa - Yingzao fashi yanjiu zai Zhongguo xueshutixizhong de yiyi [The significance of the study of Yingzao fashi in the academic system in China]," Jianzhu xuebao [Architecture Journal] (January 2017): 30-4. 
and founded the department of architecture. After the establishment of the People's Republic of China in 1949 he continued to hold important posts related to construction in the new government. During the Cultural Revolution Liang was treated extremely unfairly, as were many other intellectuals; he died in 1972, as the turmoil was just ending. After the reforms and opening up that began in 1978, Liang was quickly rehabilitated, his academic contributions praised and his reputation further enhanced. Ultimately, he became known both as the father of modern Chinese architecture and as the explorer and protector of ancient buildings as cultural heritage. Today, among the many distinguished national intellectuals of the early twentieth century, Liang and his wife Lin stand out as cultural icons.

Between joining the Society in the 1930s and the foundation of the People's Republic of Chine (PRC), the couple were responsible and driving force in the Society in conducting field surveys of ancient buildings across the country and published important studies in Chinese and English. Their most important and influential academic achievement was formulating a historical sequence of development for China's ancient architecture: focusing on the timberframed structures of important classical official buildings from the Tang (618-907) to Qing (1644-1911) dynasties, a clear evolution of style appeared. The reason Liang and Lin worked on this evolutionary process was to infer the direction of China's future architecture, which was actually very ambitious. Research shows that the couple were influenced by French structural rationalism ${ }^{21}$. If the structurally rational Gothic buildings of France had laid the foundations for modern buildings made of steel, cast iron and reinforced concrete, then, Liang and Lin believed, the buildings of ancient China, especially those of the Tang Dynasty represented by the Foguang Temple could likewise be transformed into modern architecture. As stated by Lin, "There are novel materials and building technologies developed in Europe and the United States, where the fundamental principles of framing system are no different than in China with a history of thousands of years in this respect. When it comes to modern factories, schools, hospitals and other buildings that require light and air, there are barely any differences between China and the West, whether in the configuration of walls, windows and doors, or the framing system of concrete or steel, except for the choice of building materials. This is exactly the prime period of revitalization for Chinese old buildings." 22 Here Liang and Lin's arguments about the transformative potential of indigenous architecture also echoed those advanced some years earlier by the Japanese architect Ito Chuta (1867-1954, see below).

Liang and Lin had a tremendous impact on Chinese architecture and the popular perception of ancient buildings, and their ideas were regarded as authoritative. Even today, few voices

\footnotetext{
${ }^{21}$ On the influence of French structural rationalism on Beaux-Arts education and indirectly on Liang and Lin, especially Viollet-le-Duc's thought, see Zhu Tao, Liang Sicheng he tade shidai, 81-100.

${ }^{22}$ Lin Huiyin, "Introduction," in Liang Sicheng, Qingshi yingzao suanli ji zeli [Building principles and regulations in Qing style] (Beijing: SSCA, 1934), 1-20.
} 
in architecture have reflected critically on their contentions. Yet comparing Liang's and Lin's ideas with Zhu's vision, developed when he founded that the SSCA, a significant discrepancy becomes apparent: the study object has been narrowed to official classic architecture and confined to timber-framed structures only. ${ }^{23}$ The remains of ancient architectural were stylised based on aesthetic criteria, and the choice of buildings considered significant was highly selective. ${ }^{24}$ Liang was principally concerned with identifying what he conceptualised as the essence of Chinese architecture within a self-contained dynamic of evolution; there was almost no discussion of the impact of foreign cultures, and few studies on craftsmanship. Zhu's goals in orientating the SSCA appears to have stayed unheard in most clearly defined intentions.

The construction of Liang and Lin's knowledge was rooted in a powerful nationalist sentiment and also reflected their Western educational background. In modernism, architecture acquired a machine aesthetic, ${ }^{25}$ and technology became the essence of modernist architectural thought. Liang and Lin chose their historical narratives in tune with current thinking; in fact, Ito Chuta had published a similarly formalist account of the evolution of Chinese architecture just before Liang joined the SSCA, in $1926 .{ }^{26} \mathrm{Zhu}$, meanwhile, attempted to reshape a systemic theory within the terms of the traditional knowledge system. ${ }^{27}$ Although an old-style literati, Zhu was obsessed with craftsmanship and held an important post with rich experience and vision. His efforts in organising the Society might have promoted the study, protection and development of traditional yingzao-related craftsmanship. But understandings of what mattered in architecture as communicated from the West, and the corresponding boundaries that grew between disciplines, were counter to Zhu's expectation for comprehensive yingzao knowledge. Shifting from yingzao to jianzhu, the domain of the newly established discipline chaged from traditional, vernacular, culture-based, building craft-related knowledge to modern, international, visually centred, building industry-linked knowledge.

Traditional culture in China underwent significant changes as the New Culture Movement of the Republican era, and then the establishment of the PRC in 1949, sought to modernise and rationalise Chinese ways. In architecture, the foundations of habitual aesthetics related

\footnotetext{
${ }^{23}$ Liu suggests that "The notion that building in China was predominantly of wood perhaps stems from an early twentieth-century consensus that developed as an outcome of the rivalry between Chinese and Japanese scholars over the survival of the earliest Tang wood architecture." See Liu, "Between the Titans," 194.

${ }^{24}$ Steinhardt, "The Tang Architectural Icon."

${ }^{25}$ Le Corbusier, Vers une architecture (Paris: Maison Crès, 1923).

${ }^{26}$ Yu Shuishan, "Ito Chuta and the Narrative Structure of Chinese Architectural History," The Journal of Architecture 20, no. 5 (2015): 884-918, on 885.

${ }^{27}$ Liu Diyu, Zhu Qiqian zhongguo yingzaoxueshe yuanqi yanjiu-jinian zhongguo yingzao xueshe chouzu 90 zhounian [Zhu Qiqian's "The Founding of the Society for the Research in Chinese Architecture": In Memory of the 90th Anniversary of the Foundation of the Society], Jianzhu Yichan [Built Heritage] (April 2019): 37-41.
} 
to the clan, rituals and religious beliefs ${ }^{28}$ were greatly affected.In addition, from the technical perspective, cheap and efficient modern technology was comprehensively popularised, all but eliminating the handicraft industry. The modern education system itself also stemed from the West, whereas traditional Chinese disciplines, with their particular formulations of humanities and social sciences, and their general approach to yingzao, do not coincide neatly with the divisions of Western disciplines. ${ }^{29}$ Seen from the outside, Liang's emphasis on traditional texts such as Gongbu gongcheng zuofa and Yingzao fashi seems to suggest that he was learning from traditional knowledge, but in fact, in interpreting these two ancient documents, and investigating surviving buildings or their remains, Liang and the members of his school documented and categorised the material forms and styles of ancient buildings, but did little to explore or explicate the knowledge systems of traditional yingzao craftsmanship.

\section{Modern practices and knowledge production by traditional Chinese carpenters: the carpenter Pan Dehua}

Traditional craftsmanship was excluded from the academic field of architecture when it was established in the 1930s, and it was almost impossible for it to enter the sphere of formal knowledge during the troubled decades from 1949 to 1978 . Through this period the industrialisation of the building industry continued, and the handicraft industry continued to dwindle. However, in some areas that had not yet been influenced by modern industrialisation, such as the vast rural areas of China, there were opportunities for local craft knowledge to be furthered in the vocational education system. In the 1970s, under the slogans "proletariats arise, become your own masters" and "serve socialism," part of the handicraft knowledge of the poor and lower-middle peasants was officially combed through to satisfy rural needs that industrialisation could not accommodate. The Carpenter, compiled in 1972 by the Guangzhou Construction Engineering Bureau, and the Rural Carpenter, compiled by the Shanghai Jiading Furniture Factory in 1979, are representative of the books which appeared in areas with developed wood craftsmanship. Organised by local technical units and vocational schools, these books record the knowledge of local craftsmanship and were intended to guide practices. They are highly practical and miscellaneous. The objects of craft knowledge are mainly

${ }^{28}$ On vernacular architecture as social and cultural space see, for instance, Ronald G. Knapp, China's Vernacular Architecture: House Form and Culture (Honolulu: University of Hawai'i Press, 1989); Ronald G. Knapp and Kai-Yin Lo, eds., House Home Family: Living and Being Chinese (Honolulu: University of Hawaii Press, 2005); Francesca Bray, "Technics and Civilization in Late Imperial China: An Essay in the Cultural History of Technology," Osiris 13 (1998): 11-33.

29 Howard Chiang, ed., The Making of the Human Sciences in China: Historical and Conceptual Foundations (Leiden: Brill, 2019). 
practical tools, such as agricultural implements, furniture and daily necessities, and less related to construction except in introducing the technology of Western truss framing. ${ }^{30}$

Traditional building knowledge must be incorporated into mainstream architectural history narratives if it is to enter the sphere of authoritative knowledge. In 1973, a year after Liang's death, construction began on the Jianzhen Memorial Hall in Yangzhou. This is a Tang Dynastystyle building designed according to Liang's early ideals, ${ }^{31}$ with reference to the Tōshōaiji Temple in Japan. ${ }^{32}$ Unlike the restoring and rebuilding of antique buildings that swept the country in the 1980s and 1990s, which mostly used modern materials including concrete and steel, the 1970s Jianzhen Memorial Hall was made of timber. The use of expensive and scarce timber created an opportunity for carpenters to re-enter the stage, and the hall also benefited from the better preservation of traditional timber-based building craftsmanship in Yangzhou, a wealthy city where financial abundance allowed for constructing timber buildings even after it had become unaffordable in many other places.

Pan Dehua (1941-) was the chief carpenter responsible for the construction. He was only 30 years old at construction time. Before construction began, he had deliberately visited the main hall of the Foguang Temple in Mount Wutai and carefully investigated the entire building. ${ }^{33}$ To create Tang-style architecture, surveying the most iconic Tang building seemed to him the best way. After the success of construction of the Memorial Hall, Pan was praised as the Young Lu Ban (Lu Ban was the patron saint of traditional carpenters, see below), and his career entered a new phase. In the 1980s and 1990s, when the economy took off and there was a great demand for masons and carpenters, he matured as a construction engineer specialising

${ }^{30}$ Guangzhou Construction Engineering Bureau, Mugong [The Carpenter] (Guangzhou: Guangdong People Press, 1972), 148.

31 As early as in 1932, Liang published his first study of early Chinese architecture study, entitled "Buddhist Monasteries and Palaces of Tang Period We Know at This Time," Zhongguo yingzao xueshe buikan 3, no.1 (1932). Much of the evidence was drawn from paintings of Buddhist paradises in the Dunhuang Caves, which Liang knew through the research of Sir Aurel Stein (1862-1943) and Paul Pelliot (1878-1945). In 1937, Liang and Lin found the Foguang temple and published their findings in 1941 in an article entitled "China's Oldest Wooden Strucure," followed in 1951 by "Ancient Chinese Architecture in the Dunhuang Wall Paintings" and "The Toshodaiji Kondo and Tang Architecture" in 1963. From the 1930s to 1960s, as the only Western-trained Chinese architect who continued to write architectural history, Liang fixed his definition of Chinese early architecture on Tang temples as represented by the Foguang temple and inferred a flow of influence from Tang Chinese to Japanese wooden Buddhist buildings, despite the known existence of earlier Japanese wooden temples, and of other newly discovered Tang buildings also of earlier date. See the detailed study of why and how Liang created the icon of the Tang temple by Steinhardt, "The Tang Architectural Icon."

32 Jianzhen (688-763) was a Chinese monk who spread the Buddhist faith in Japan. He founded the Tōshōdaiji, completed in 759, soon after his arrival in Japan in 754. Its Golden Hall (kondō), reconstructed in 1709, is now a National Treasure.

33 Yong Jianming, "Jianzhen jiniantang gongdi de qingnian luban" [The young "Lu Ban" in the construction site of the Memorial Hall of Jianzhen], Jianzhu Gongren (September 1983): 4-5. 
in antique construction and restoring ancient buildings. He thus changed his social identity from carpenter to architect and directed a series of prestigious restoration projects including more than ten major temples or ancestral halls. ${ }^{34}$ Most of the restored buildings had reinforced concrete structures with a few decorated parts in wood, such as the timber dougong of the eaves.

Dougong were thus reduced to decorative elements in the physical structures of the buildings having undergone restoration. But manually they were undergoing a revival in which Pan and his technical skills as a carpenter played a key role. During the 10 years from the late 1990s to the early 2000s, Pan, together with his sons and some carpenters, made more than 120 dougong models by hand, after referring to the two classic books Yingzao fashi and Gongbu gongcheng zuofa, which the SSCA had explored in its early days. Further refining those works' principles of organisation by size and style, a corresponding book, Dougong was published in 2004, in three chapters: The first gives full coverage of the architectural history constructed by Liang, treating the dougong separately as a material symbol of historical evolution and adding more archaeological materials; the second discusses the detailed drawings of the Song-style dougong in Yingzao fashi; and the third presents detailed drawings of the Qing-style dougong in Gongbu gongcheng zuofa. In an online article about Pan and his book, it was said that the book of Dougong completed the unfinished research initiated by Liang Sicheng and Liu Dunzhen. ${ }^{35}$ Here we should note that Pan had studied with Luo Zhewen (1924-2012), an architect and conservationist who had in turn studied with Liang and was one of the most ardent supporters of Liang's principles. Among his students, Luo had taken on three carpenters as his disciples. Pan was thus a disciple's disciple of Liang, a spiritual grandchild. ${ }^{36}$

The year it was published, Pan's book with its elegant bindings and fine drawings won the highest domestic publication prize, the Chinese Government Award for Publishing. The second edition, published in 2011, was revised to focus solely on the dougong's form and theories about its evolution, never veering from Liang's academic scope of architectural history. Despite Pan's hands-on carpenter's expertise, the book made little mention of the technical information related to dougong, such as how to make one.

\footnotetext{
${ }^{34}$ Among them, the Yuewang Temple of the Sheng Ancestral Hall, the Qiling Pagoda of Daming Temple, the Tianzhong Pagoda of Gaomin Temple, the Phoenix Pagoda of Phoenix Island, the Wanfo Pagoda of Kaiyuan Temple, the Bi Pagoda of Lin Sanzhi's Former Residence, and the Lengyan Pagoda.

${ }^{35}$ Mugong daoju luntan [The carpentry tools forum], "Pan Dehua xiansheng daibiaozuo dougong de qianshijinsheng" [The past and present of the book of Dougong], Kandian kuaibao, March 12, 2019, https://kuaibao.qq.com/s/20190312A0IUU000.

36 Ibid. In this article, Luo Zhewen was praised as "not making any job discrimination" when he accepted carpenters as his disciples. This narrative exactly reveals the inequality between the learned and the skilled.
} 


\section{Transmission of vernacular Chinese local craftsmanship: Lu Ban jing}

Unlike the revitalisation of architectural engineers and official buildings in the 1990s, residential buildings in some of China's rural areas were still constructed using traditional, non-Western techniques. The tradition of building houses with wood had almost disappeared in the north by the 1990s, but survived in the southern Fujian-Guangdong area and the mountainous areas of Yunnan-Guizhou and Hubei-Hunan regions, where traditions of wood craftsmanship are still passed down together with the relevant ritual beliefs and life customs. ${ }^{37}$ Building craftsmanship was closely connected with beliefs relating to Lu Ban, the most important record of which was the fifteenth-century compilation known as Lu Ban jing (Lu Ban's Classic, or The Carpenters' Canon), whose contents were widely familiar to ordinary craftspeople. ${ }^{38}$

The practicalities of house building were not the main contents of Lu Ban jing. The book said more about customs, rituals and taboos. As one researcher on Lu Ban jing, Klaas Ruitenbeek, wrote in the preface of his monograph, "In the building field, technique, ritual and magic were linked closely from the beginning." ${ }^{39}$ Investigations of the vernacular transmission of building carpentry in China's southern provinces confirm these links. Chen Yaodong's research, for instance, shows that for the folk carpenters in the Fujian-Guangdong region, engineering knowledge-styles, dimensions, practices, etc.-was generally passed on from generation to generation through lineage, with formulas, tools, drawings, etc. as the medium. Yet the secret knowledge that related to fengshui, rituals, taboos, etc., was often passed down through families in the form of manuscripts. ${ }^{40}$ Chen also indicated that there are multiple editions of $L u B a n$ jing covering the contents in manuscripts he found in the hands of local carpenters. Those manuscripts (秘本) passed down in the families of carpenters might be the hand-copied books originating from $\mathrm{Lu}$ Ban jing (刊本). ${ }^{41}$ According to Guo Husheng, in a traditional society since as early as the Ming Dynasty, the guilds of building had emerged, and it was common for them to be named after Lu Ban (鲁班会). Those guilds were responsible for the management and regulation of the trade of building in different ways. The content in $L u$ Ban jing, especially

37 The author has recorded the technical system of building houses in the Nandong area of Guizhou in the form of ethnography; Ren Congcong, Bian Ruchen, Li Simiao, "On Technology and Ritual of Chuandou House Construction in Southwest China: the Case of Dong Minority Area," Built Heritage 2, no. 1 (2018): 39-48.

${ }^{38} \mathrm{Lu}$ Ban, a legendary carpenter of the fifth century BC, was said to have improved many basic carpentry tools and invented various ingenious devices; by Ming times he was the patron deity of the carpentry guilds.

39 Ruitenbeek, Carpentry and Building in Late Imperial China, 2.

${ }^{40}$ Chen Yaodong, Lu Ban jing jiangjiajing yanjiu [Research on Lu Ban jing Jiangjiajing] (Beijing: China Architecture \& Building Press, 2010), 90-1.

${ }^{41}$ Ibid., 4-5. 
those in relation to the worship rituals about saint $\mathrm{Lu}$ Ban, revealed that the character of this book is more of trade standards. ${ }^{42}$

Lu Ban jing had many versions that were widely circulated and often appeared in southern book markets up to the end of the Qing Dynasty. It was possible to find locally produced manuscripts regarding fengshui and construction in local markets all over southern China even into 1990s. The earliest version currently known is Lu Ban yingzao zhengshi (Lu Ban's standard models for building), was published in the Ming dynasty (1368-1644). Research shows that some designations for administrative units mentioned in this version date back to the Yuan dynasty (1279-1368), which suggests the existence of earlier editions, but references in the text to the Ming legal code show that this version cannot be earlier than the Ming. ${ }^{43}$ From the Qing dynasty, a version known as Lu Ban jing jiangjiajing (Lu Ban's mirror for craftsmen) dominated, which provided more fengshui-related contents than the Lu Ban yingzao zhengshi. According to Chen, due to the prevalence of fengshui practices in folk culture from the Ming Dynasty, carpenters absorbed part of that knowledge to take on the role of fengshui masters; the fengshui contexts of the new versions of the Lu Ban jing were often copied from specialist fengshui works. As building could not be carried out without the appropriate ritual calculations and performances, this combination of expertise was also a winning situation for small householders, allowing them to save costs. ${ }^{44}$

As far as modern architecture was concerned, Lu Ban jing received far less attention than Yingzao fashi or Gongbu gongcheng zuofa, mainly because it was considered superstitious, and architecture scholars did not recognise it as having value even for social science. Moreover, scholars of the time considered the book to be about folk buildings, whereas the significant or typical architecture of each era was, in their view, represented in its official and monumental buildings. From the perspective of ancient Chinese building craftsmanship and culture, however, folk and official constructions were closely related, As Zhao Chen says: "In Chinese building culture there are no such divisions between 'Classic' and 'Anonymous' as in Western culture, only differences between official and folk buildings, and here the two kinds are not distinct, but rather different in grading. They still belong to a unified system." ${ }^{35}$

As the story of the Lu Ban jing's exclusion suggests, however, the official narratives of China's architectural history produced in China followed Liang Sicheng in focusing on grand

${ }^{42}$ Guo Husheng, "Lu Ban jing pingshu" [A review of Lu Ban jing], in Zhongguo gudai jianzhu jishushi [The history of ancient Chinese building technology], ed. Institute for History of Natural Science, 541-4 (Beijing: Science Press, 2000), 542.

${ }_{43}$ Chen, Lu Ban jing jiangjiajing yanjiu, 97.

44 Ibid., 18-9.

${ }^{45}$ Zhao Chen, "Guanyu tumu/yingzao zhi xiandaixing de sikao" [Thoughts about the modernity of tumulyingzao ], Jianzhushi [Architect] 158 (2012): 17-22. 
buildings and leaving vernacular ones aside. Paradoxically, one key factor here was the antielitist political struggles of the Cultural Revolution. In the 1950s Liu Dunzhen and a few colleagues had begun research and publication on vernacular architecture, but their pioneering work on unappreciated building forms and skills was cut short by the convulsions of the Cultural Revolution. By the time the turmoil ended huge numbers of traditional buildings had been destroyed and replaced with more "modern" structures. Only in the 1980s and 1990s did research on vernacular architecture tentatively resume, and much of the work was "morphological rather than historical" focusing on building structures to the exclusion of the material culture of building practice and use that Zhu Qiqian had advocated. ${ }^{46}$

\section{From "Zouka" to "Kenchiku”: the establishment of modern Japanese architecture}

In 1877, the new Public Works Ministry of the Meiji government, founded in 1870 to promote modern industrialisation, established the Imperial College of Engineering in Tokyo. The Zouka department (literally "house construction department") was established to train architects. In the following year, Kenchiku Zashi (literally "building journal") began publishing. In those early days the two Chinese words Zouka (造家) and Kenchiku (建築) were both used to correspond to the term architecture, recently introduced from the West. At first the Zouka department introduced European historicist architecture; its first professors were the British architects Charles Alfred Chastel de Boinville and Josiah Conder, who educated the first generation of local architects such as Tatsuno Kingo, Katayama Toukuma and Sone Tatsuzou. Accepting the values of European historicism, these architects would adopt either Classical European or Gothic styles in their designs. ${ }^{47}$

The second generation of architects, represented by Ito Chuta, began to explore local aesthetics. In 1893, Ito published "On the architecture of Horyuji Temple" in Kenchiku Zashi, indicating that the Japanese architects were beginning to focus on local historical relics (Figure 3). In 1897, the Zouka discipline was renamed Kenchiku at Ito's suggestion, reflecting his influence. ${ }^{48}$ After

46 On the historiography of vernacular building in China, see Ronald G. Knapp, "In Search of the Elusive Chinese House," in House Home Family: Living and Being Chinese, ed. Ronald G. Knapp and Kai-Yin Lo (Honolulu: University of Hawaii Press, 2005), 37-42. The quotation is from page 40.

47 Japanese architectural historian Fujimori Terunobu wrote, "What Japanese architects in Meiji Era firstly learned from was the historicist architecture of the nineteenth century, which took European historical architectural forms as examples. Only in the twentieth century did designers begin to seek all kinds of forms out of their own thoughts." Fujimori put the local architects of the Meiji era into three categories: English school, French school and German school. See Fujimori Terunobu, Nihon no kindai kenchiku [Japanese modern architecture], 17th ed. (Tokyo: Iwanami Shoten, 2011), 209-67.

${ }^{48}$ Nakatani Norihito traced the history of translation of the term "architecture" into Japanese through the Bakumatsu and Meiji eras (1850s-1910s). He wrote that although it is usually thought that the term 
exploring Horyu-ji Temple, Ito spent 3 years travelling and exploring North Korea, China, India, Turkey and other Asian areas starting in 1902. After returning home, he developed his theory of architecture evolution, in which he wrote: "There is still plenty of opportunity for Japan to change the materials and forms of timber-framed buildings. If the conditions of transition from wooden buildings to Doric ones, such as Greece enjoyed, are provided to Japan, then Japanese wooden construction too can be transformed into a stone order." ${ }^{\prime 9}$ We can see the similarity between Lin's prospect in 1930s for Chinese timber buildings evolving into western construction. Inspired by the second generation of architects led by Ito, the third generation actively began using new material technology to evolve traditional wooden houses and buildings. The representative styles of this period included the now infamous Imperial Crown style, which in the 1930s, under the militarism that prevailed Japan, was promoted as a standard for official buildings. ${ }^{50}$

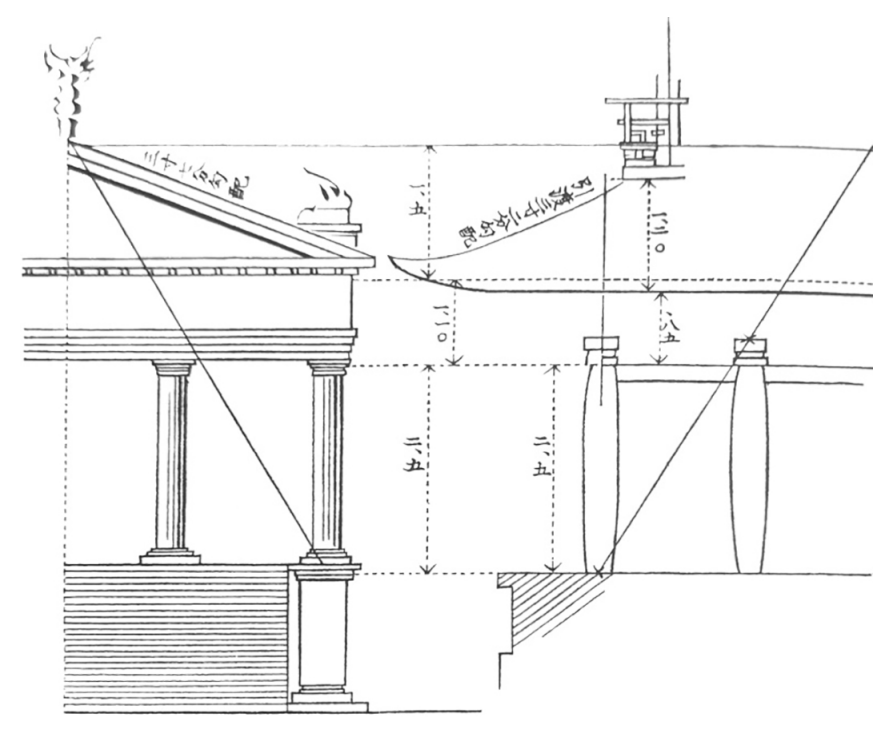

Figure 3. A comparison between Horyu-ji Temple and Greek temple. Ito Chuta, "On the architecture of Horyuji Temple,” Kenchiku Zashi, 1893. Public domain.

Zouka is more connotative of engineering, while the term Kenchiku is more artistic, this is in fact wrong: it is exactly the opposite. Zouka, writes Nakatani, implied the meaning of creativity, while Kenchiku was a more general definition of all kinds of structure. The reason why Ito argued for adopting Kenchiku rather than Zouka, then, was that he wanted to cloak his artistic point of view with the authority of engineering. See Nakatani Norihito, Kinsei kennchiku ronshyu [Pre-modern Architecture Theory] (Osaka: Acetate, 2004), 326-55.

49 Ito Chuta, "Kenchiku shinka no gennsoku yori mitaru wagakuni kennchiku nozennto [Looking forward from the principles of architecture evolution to the future of our country]," Kenchiku zashi 265 (1909): 4-36.

50 During the 1930s, in many competitions for major public buildings, Japanese taste was specifically required as a design criterion; Isozaki Arata, Kenchiku ni okeru nihon-teki na mono [Japan-ness in Architecture], 5th ed. (Tokyo: Shinchosha Publishing, 2010), 13. 
Meanwhile in the academic field of Japanese architecture, along with the rise of modernism, architects such as Horiguchi Sutemi (1895-1984) began to fight back against historicism almost immediately, with theories also derived from traditional architecture. ${ }^{51}$ Japanese chashitsu (tea-ceremony houses), sukiya (residential houses developed from tea-ceremony houses), gardens, etc., began to win admiration. Their elegant appearance, functional spaces, and tectonics made them easy to appreciate in the terms of modern aesthetics. In fact ever since Meiji Japan opened to Westerners in the late nineteenth century, Western scholars had noted the modern quality of space in traditional Japanese architecture. ${ }^{52}$ From the 1920 s to 1940s, with more Western modernist architects including Bruno Taut (1880-1938), Antonín Raymond (1888-1976), Frank Lloyd Wright (1867-1959) and Walter Gropius (1883-1969) visiting and working in Japan and introducing Japanese traditional architecture to the West, the paradigm of cognition for traditional architecture had shifted from Ito's formalist approach to the modernist approach. Some would argue that the West "discovered" Japan through "the filter of western architectural values." ${ }^{33}$ Nevertheless, the relevant point for this paper is the comparison with China. In the architectural section of Japan, there had been a trend of criticizing the historicism in architectural design represented by the styles of imperial crown, as reflected in the imperialism and militarism of Japan. While in China, it is not that early architects wouldn't want to integrate modernism into architectural design, nation forms prevail due to cultural and political needs.

\footnotetext{
${ }^{51}$ Kenchiku youshiki ronnsou [Essays on architecture styles] edited by Itakaki and Horiguchi was published in 1932. In this book, Horiguchi contributed two essays. One is about Japanese tea-ceremony house, and in the other he directly criticized the imperial crown styles, or so-called Japanese taste at the time (Takao Itagaki and Sutemi Horiguchi, Kenchiku youshiki ronnsou. [Tokio: Rokumonkan, 1932], 133); see also the English translation, Horiguchi Sutemi, Robin Thompson (translator), "Japanese Taste in Modern Architecture," Art in translation 4, no. 4 (2012): 407-34.

52 The first detailed Western study of Japanese architecture was written by the American zoologist and archaeologist, Edward S. Morse, Japanese Homes and their surroundings (Boston: Ticknor, 1886). The text was illustrated with simple line-drawings of traditional Japanese dwellings and made frequent reference to the tasteful simplicity and asymmetry of Japanese architecture. Morse was hired as professor of Zoology from 1877-1880 in the Imperial university (later the University of Tokyo), of which the Imperial College of Engineering became part in 1886. See Peter McNeil, "Myths of Modernism: Japanese Architecture, Interior Design and the West, c. 1920-1940," Journal of Design History 5, no. 4 (1992): 281-94.

53 As quoted in Hiroshi Adachi, "The Japanese House: Discovering Aesthetics and Space," in Japanese Aesthetics and Sense of Space. Another Aspect of Modern Japanese Design (Tokyo: Sezon Museum of Art, 1990), 297.
} 


\section{The modern practices and knowledge production of Japanese traditional carpenters: the carpenter Nishioka Tsunekazu (1908- 1995)}

Due to frequent earthquakes, heat and humid weather, there has been a tradition in Japan of rebuilding wooden buildings. ${ }^{54}$ Traditionally, this work was contracted to a team of woodworkers headed by the chief carpenter. After the Second World War, the Great Showa Repair of the Buddhist temples and monuments in the Horyuji area ushered in a new era of repairs to what in East Asia is called cultural relic architecture. ${ }^{55}$ The new system allowed for adding modern architects and engineers to the jobs originally completed by chief carpenters. Meanwhile, there was also a robust rebuilding programme of traditional landmarks and much construction of new-built pseudo-classical buildings.

Confrontation between architects and carpenters may be inevitable at the repair sites of cultural relic architecture and the rebuilding sites of pseudo-classical architecture. In China, traditional carpenters have weak discursive power and are dependent on architects. In Japan, especially on important construction sites of ancient buildings, master carpenters belonging to important lineage groups are incorporated into the project committees. Their discursive power is greater, and they often argue with architects. A representative figure was the hereditary chief carpenter of Horyuji Temple, Nishioka Tsunekazu.

Three generations of Nishioka's family acted as chief carpenters of Horyuji Temple. The statefunded Showa repair project began in 1934. In 1939 several of the major structures were disassembled piece by piece; Nishioka worked on the dismantling, during which he made some important inferences about how the timbers had originally been sourced, worked and assembled. After they were dismantled, the Horyuji timbers, tiles and other elements were put in storage and war interrupted the project. In 1949 a fire occurred in the Golden Hall (the main hall) of Horyuji Temple; when reconstruction began Nishioka officially became the chief carpenter. By 1959, the Golden Hall, the five-storey pagoda and other ancillary buildings had been restored. After the repair of Horyuji Temple, Nishioka also participated in the repair and rebuilding of many other iconic heritage buildings including the five-storey pagoda of Myoo-in Temple in Hiroshima, the main hall and the three-storey pagoda of Horinji Temple, the west

\footnotetext{
${ }^{54}$ Larsen Knut Einar, Architectural preservation in Japan (Trondheim: Tara Publishers, 1994).

55 Cultural relics (wenwu in Chinese, bunbutsu in Japanese) refers to objects of historical and cultural value, ranging from antiques to archaeological sites or palaces. Showa (1926-1989) is the name of the reign of Emperor Hirohito. The Horyuji Area (a UNESCO World Heritage site since 1993) contains about 50 Buddhist monuments, among the earliest in Japan.
} 
tower and Golden Hall of Yakushi-ji Temple. Nishioka was known as the "Last Generation of Palace Carpenter" in Japan. ${ }^{56}$

During the Great Showa Repair of Horyuji, it was agreed that the roof of the Golden Hall should be restored to its Asuka Era (sixth-eighth century) form. ${ }^{57}$ But what was that form? Architectural historians held different views from Nishioka. Based on the roof style of an architectural model from the Asuka Era, the Tamamushinozushi, ${ }^{58}$ that had been preserved in Horyuji Temple, the leading architectural historian Fujishima Kaijirou (1899-2002) claimed that the Golden Hall's roof in the Asuka Era must have taken the form called Shikoro Yane. However, inferring from the original materials and the nail marks adopted in the early construction, which he had found during the disassembling work, Nishioka believed the roof form was Irimoya. Typically, the architectural historian justified his argument by invoking a stylistic chronology, while the carpenter grounded his argument in experience, namely the personal observation of how the original building had been assembled from the inside out. In the end, Nishioka prevailed, and the Iirimoya style was adopted.

The three-storied pagoda of Horinji Temple was struck by lightning in 1944. In 1965 it was rebuilt in the Asuka form instead of its previous form. The architect Takeshima Takuichi drew the plans, and Nishioka was responsible for construction. ${ }^{59}$ The big debate between the two regarding using steel for reinforcement was even published in the newspaper. ${ }^{60}$ Takeshima held

56 As of 2017, there were around 100 hereditary palace carpenters and five companies operating in Japan, according to "Koto ni sasaeru waza" [The technology supporting ancient capital], Nihon Keizai News, July 7, 2017. In the past, the term palace carpenters referred to lineages in the exclusive service of shrines, temples and palaces. The carpenters worked mostly away from home, moving to construction sites as required.

57 Rebuilding in the original form seems the general principle for heritage conservation in Japan in modern times. But in fact almost no ancient buildings still preserved today retain their original form. Criticised today, in earlier times this adaptation to contemporary taste was still quite normal in Japan.

58 Tamamushinozushi is a 2 metres high building model stored in Horyuji temple dating back to seventh century. Zushi is a name for this kind of Buddhist artwork. It is usually a small-scale representation of a timber building which may or may not exist in the real world. In Chinese Buddhist temples a similar type of artwork from various periods can be found. In Yingzao fashi, such objects are called fodaozhang or jingzang.

59 Horinji temple is located 1 kilometer north of Horyuji temple. The Nishioka family used to be in charge of the construction and repair for this temple too. Nishioka's grandfather kept a detailed 1:10 drawing of this pagoda. However, in the 1960s rebuilding project, Takeshima was appointed as architect and drew a new Asuka-style drawing. The way he "designed" an Asuka era pagoda was to take the 1 st, 3rd and 5th stories of Horyuji temple's five-storied pagoda and combine them-totally a graphic industrial way of "creating" things.

${ }^{60}$ See the debates in Mainichi News, April 9 and 15, 1975. Takeshima wrote the first article entitled "The design and construction of the pagoda of Horinji-The future plan with fewer craft secrets," quite an acrimonious title! What Nishioka wrote in reply the next week was entitled "Tree's life," which he later used as a book title. Nishioka Tsunekazu, Ogawa Mitsuo and Shiono Yonematsu, Ki no inochi ki no kokoro-tenchijin [Tree's life. Tree's heart- Sky, Earth, Human] (Tokyo: Shinchosha, 2005). In the book, Nishioka introduced the traditional knowledge about trees and people's relation with nature and 
the view that it was necessary to add steel to the structure according to modern engineering standards, while Nishioka, based on the practices of Horyuji Temple, believed that steel was less durable than hinoki (Japanese cypress). The outcome of their debate was to use the minimum amount of steel, only one third of what was originally called for.

When the Golden Hall was being repaired, Nishioka noticed processing marks on the columns that had been left by a special tool that had disappeared from Japanese practice, the yarigana. After combing through archaeological reports and the Shosoin museum's collection of ancient yarigana, Nishioka spent three years working with the Japanese swordsmith Mizuno Masanori to restore this lost tool. ${ }^{61}$ The difficulty of the restoration lay in both the materials and the necessary skills: since modern-day iron could not meet the requirements, they repurposed the iron from the wakugi (traditional square nails) used in ancient buildings in the Asuka Era. ${ }^{62}$ In contrast to contemporary Japanese tools, using the yarigana requires a specific hold, posture and gestures for applying force; Nishioka referred to ancient images of carpenters using a yarigana for guidance (Figure 4). ${ }^{63}$ The tool allowed for separating rather than cutting open the wood cells so that water could not intrude the cells. This technique improved the wood's anti-corrosion performance, and Nishioka stressed repeatedly that it was for this reason that the columns of Horyuji Temple could withstand corrosion for 1300 years. ${ }^{64}$

technology out of his own experience and sensibility.

${ }^{61}$ Nishioka Tsunekazu, Aoyama Shigeru, Ikaruga no takumi miyadaiku sandai [Three generations as palace carpenters in Ikaruga area], 6th ed. (Tokyo: Tokuma Shoten Publishing, 1981), 214-6; Ikaruga is the name of the place where Horyuji temple is located. The Shōoōin, located in Tōdaiji, is a repository of thousands of objects donated to the temple by the royal family during the eighth century. Today it is an invaluable source of information for the material culture of the period.

${ }^{62}$ Yarigana were made with a forge-welding technique popular in East Asia since ancient times. Earliest artefacts date back over two thousand years; Donald B. Wagner, "Ferrous Metallurgy, Volume 5, Part 11 " in Science and Civilisation in China, ed. Joseph Needham (Cambridge: Cambridge University Press, 2008), 131, 273. A written description of the technique appears in the Tiangongkaiwu of 1637. Forge welding is a solid-state welding process that joins steel to iron by heating them to a high temperature and then hammering them together. According to Nishioka and to interviews the author has done with Chinese blacksmiths, modern industrial iron requires heating to a higher temperature to be welded. Traditionally made iron "feels" softer and stickier to the wood; Nishioka Tsunekazu and Kohara Jirou, Houryuji wo sasaeru ki [Trees that support Houryuji Temple], 69th ed. (Tokyo: NHK Books, 1995), 52. Tools like yarigana need to remain very sharp to do the job which means the carpenter needs to keep sharpening it. Tools made from traditional iron are easier to be sharpened because the iron contains micro-holes that make it easier to shave off a thin layer.

${ }^{63}$ Even after restoring the tool, it proved impossible to use without the proper coordination of gestures. Nishioka said he got some inspiration from old paintings but didn't mention where he saw them (Nishioka, Ikaruga no takumi, 217-18). In Nakamura, Daiku dougu no rekishi [The history of carpenters' tools] (Tokyo: Niwanami Shoten Publishing, 1968), several ancient paintings with yarigana and its using scene are photocopied and published. Including Kitanotenjinengi (thirteenth century) and Kasuga Gongen Genki (forteenth century).

${ }^{64}$ Nishioka Tsunekazu, Takata Kouin and Aoyama Shigeru, Yomigaeru Yakushiji shitou [The returning of west tower of Yakushi-ji Temple] (Tokyo: Soshisha Publishing, 1981), 216-7. 
The special shape of the yarigana and the skills required to use it, together with the wavelike handmade marks left on the processed wood and the beautiful curling of the shavings are a 'performance' of unique craftsmanship in the eyes of modern people ${ }^{65}$ Combined with the legend of the Golden Hall that has stood for a thousand years, the many stories about Nishioka's efforts have made the restoration of the yarigana a modern myth. We often hear that modern people cannot recreate Stone Age artefacts, but Nishioka seemed to be a carpenter who had travelled in time from the Asuka Era, and his skills looked like a myth coming true. Reintroducing the yarigana was a tremendous success, and Nishioka went on to use the tool in many repairs and restorations of ancient buildings. He also trained many carpenters to use it, and its use has since spread far and wide. Following the reintroduction of the yarigana, not only domestic carpenters but also carpenters and blacksmiths abroad began to copy and use this legendary tool. They posted images of themselves trying to make it on Facebook and other online platforms. ${ }^{66}$

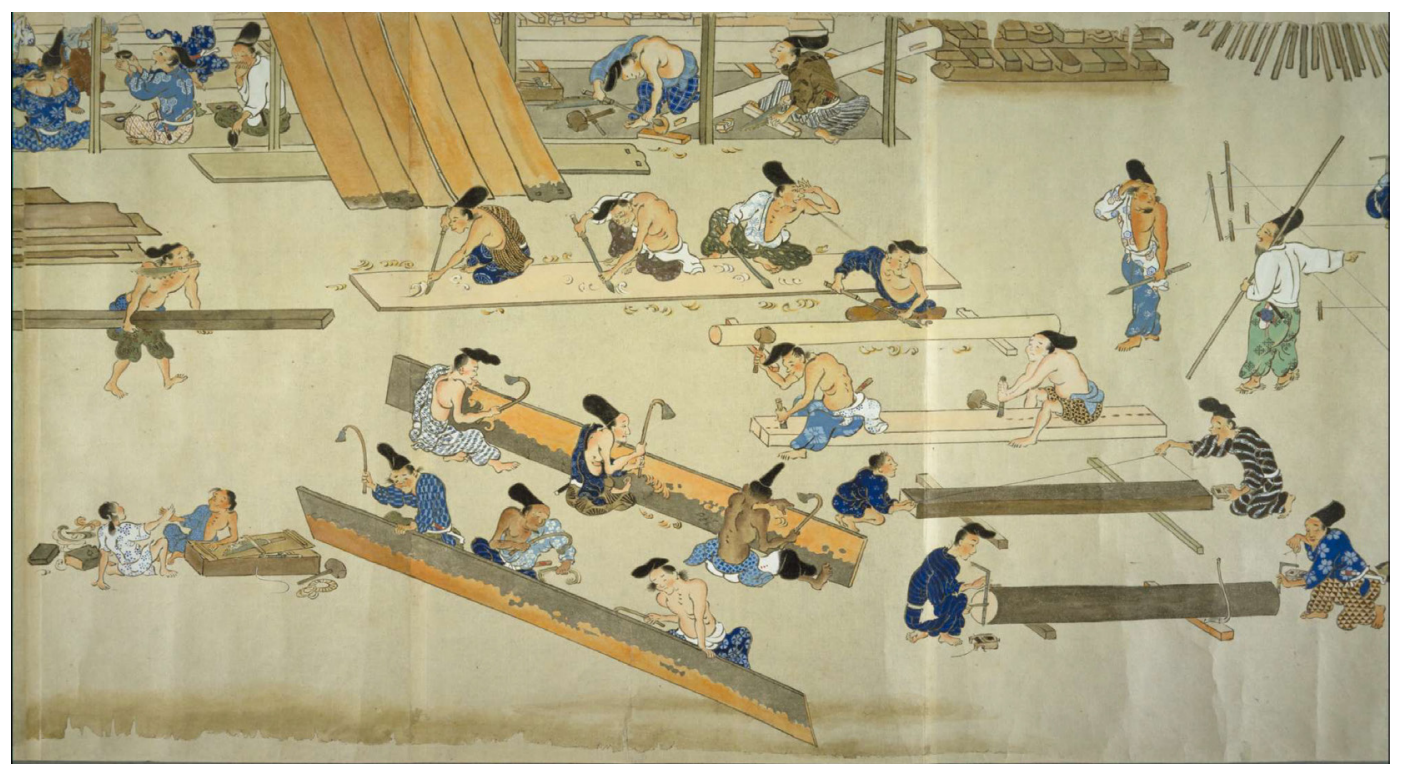

Figure 4. Kasuga Gongen Genki-Japanese emaki from Kamakura Era. Volume1. The original was painted by the royal painter Takashina Takakane, 1309. Itabashi Tsuraocopy, 1870. Public domain.

Nishioka frequently exchanged opinions with intellectuals, and beginning in the 1970s, folklorists, architects and wood materials researchers laboured to explore and record his practices and thinking; their books, as many as 30, are often written in the form of dialogues with the master carpenter. Even after Nishioka's death, scholars continued compiling books

${ }^{65}$ The ideal usage of yarigana is to peel off intact layers of wood fiber. Because the wood fiber does not lie straight in the tree trunk, this peeling process leaves a smooth but concavo-convex surface (Ibid.).

${ }^{66}$ One of the blacksmiths who succeeded in making a yarigana named Jim Blauvelt from the US. One can find his posts about making yarigana through his Facebook homepage. 
about him; his works became an important part of Japanese woodworking culture. In addition to books, Nishioka also frequently appeared on TV programmes, becoming a cultural icon.

Whereas in China the knowledge of architects and carpenters followed quite separate tracks, Japanese architecture in modern times saw more cooperation and exchange of academics and craftsmen. There are many organisations and experts from different fields involved in research on traditional craftsmanship, especially traditional tools. For example, one key figure was Matsumura Teijiro (1924-1997), an architectural historian who visited blacksmiths one by one every week with a photographer in the 1970s and then serialised the interviews in the newspaper with exquisite pictures that presented the tools like works of art (Figure 5). ${ }^{67}$ Matsumura then published a monograph on the tools. ${ }^{68} \mathrm{He}$ also served as president of the Japanese Tool Research Association, established in the 1980s. The association, which brought together professional researchers and carpenters, featured regularly in publications of the times, offering pieces that appealed to practitioners as well as enthusiasts of archaeology, design and architecture.

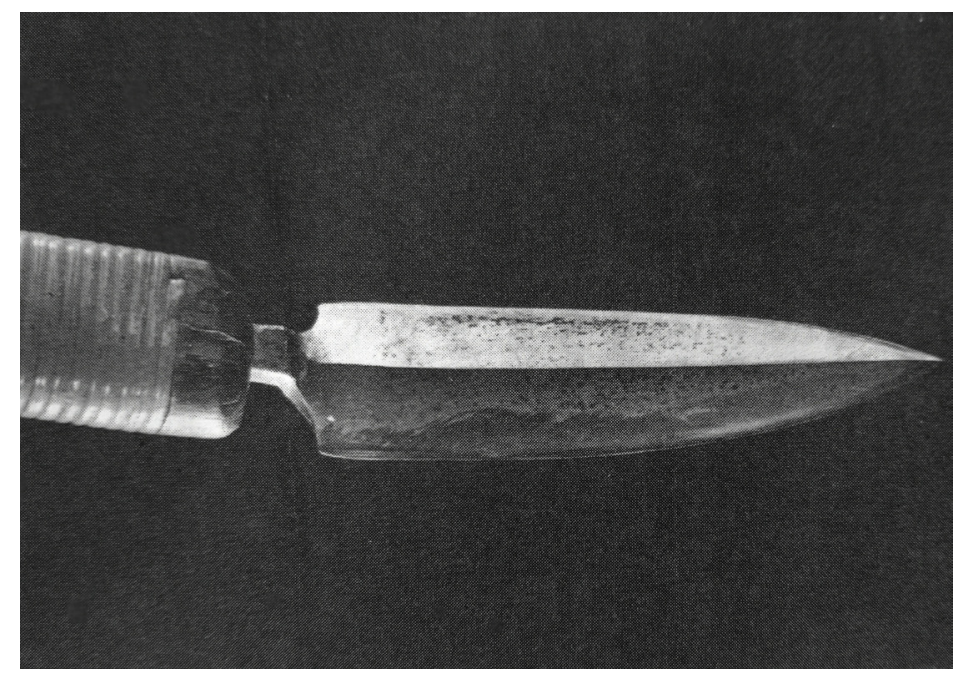

Figure 5. Close-up image of a yarigana. 1960. @Kochi Prefecture, Ishimoto Yasuhiro photo center.

\footnotetext{
${ }^{67}$ One frequently finds similarities between photos of Japanese katana swords and carpentry tools; the former have become famous collector's items worldwide. Typically taken with a large-aperture lens, the metal texture of the blade is well presented to show its sharpness. Figure 5 was taken by the famous Japanese photographer Ishimoto Yasuhiro, who also acted as photographer for the book Katsura (1960), a photo album of Katsura Imperial Villa in Kyoto.Walter Gropius, Tange Kenzo and Ishimoto Yasuhiro, Katsura: Tradition and creation in Japanese architecture (New Haven: Yale University Press, 1960). In one sense it could be said that the publication of Katsura in the US helped set the modern aesthetic standard on Japanese traditional architecture. See discussion in previous section.

${ }^{68}$ Matsumura Tejiro and Okamoto Shigeo, Dougu mandala [Tools collection] (Tokyo: The Mainichi Newspapers Co., 1976).
} 
These forms of knowledge production can be seen as generating discursive power for traditional chief carpenters like Nishioka. But their high status can also be related to the modernisation of the traditional building trade. Three of Japan's five major modern building contractors, the Shimizu, Kajima and Takenaka Corporations, were founded by local chief carpenters in the nineteenth century (1804, 1850 and 1899 respectively). In particular Shimizu Kisuke, the founder of Shimizu Corporation, was a chief carpenter who had participated in the repair of the important shrine Nikko Toshogu, and the forefather of the Takenaka Corporation even served as a retainer of the famous general Oda Nobunaga, as early as 1610. These modern construction companies have conserved some genes of the traditional wooden architecture industry, and as such, the traditional carpenter culture is also regarded as part of the corporate culture, justifying its financial support. For example, the repair of the three-storied pagoda of Horinji Temple over which Nishioka presided was primarily sponsored by the Shimizu Corporation, which was willing to spend the extravagant cost to import large-diameter Hinoki cypress trees from Taiwan for the construction. Meanwhile, Takenaka opened Japan's largest wooden tool museum in Kobe, which employs many researchers to study the history of tools in order to promote traditional woodworking.

\section{From 'guiju' to 'kikujutsu'- the generation and transmission of Japanese local craftsmanship}

Guiju is a Chinese compound word: guiv (规) refers to the compass and $j u$ (矩) to the ruler. A common motif in Han Dynasty (206 BC - AD 220) stone reliefs shows the gods of the creation myth, Fuxi and Nüwa, holding the gui and $j u$ which symbolise ordering the cosmos into the sphere of the heavens and the square of the earth. ${ }^{69}$ This Chinese term also frequently appears in much of the classical literature of the pre-Qin Dynasty, such as the canonical work of moral philosophy and statecraft Mengzi, which said, "Nothing can be accomplished without norms or standards." ${ }^{70}$ Extending from the tools that carpenters use to draw circle and square to a legal system that regulates human relations, the classical pre-Qin literature commonly discusses the relationship between man and nature in human culture using craft-related terminology, ${ }^{71}$ and the term guiju is still in use in modern times, with the broader meanings of rules, etiquette or old practices. ${ }^{72}$ However, in interviews with traditional Chinese carpenters, the author noticed

${ }^{69}$ Charles Le Blanc, "L'invention du mythe de Fuxi et Nügua," in Approches critiques de la mythologie chinoise, ed. Charles Le Blanc and Rémi Mathieu, 249-307 (Montréal: Presses de l'Université de Montréal, 2018), http://books.openedition.org/pum/19075.

70 The Chinese original text is, “不以规矩, 不能成方圆,” Li Xueqin, ed., Mengzi zhushu [Annotation of Mengzi] (Beijing: Peking University press, 1999), 185.

${ }^{71}$ Michael Puett, The Ambivalence of Creation: Debates Concerning Innovation and Artifice in Early China (Stanford: Stanford University Press, 2002), 39-91.

${ }^{72}$ According to Xiandai hanyu cidian [Modern Chinese dictionary], 7th ed. (Beijing: The Commercial 
that carpenters still use guiju as a term that specifically refers to certain inherited practices related to crafted objects, including tools and components, and overall building features such as dimensions and styles. These guiju are often passed down through the carpenters' lineage in the form of formulas and secrets. The term appears in Yingzao fashi too: "Carpenters pay attention to the guiju. In various works, comparison of the pros and cons depends on the size of the object and there are methods for measuring the pros and cons ... or if there is a need to draw a picture for setting up guiju, one will be specially drawn to clarify the guiju."73 Guiju as used by carpenters in China past and present has metaphorical or even moral significance, implying an inherited standard for procedures properly performed.

There has always been exchange between China and Japan in building craftsmanship; beginning with the early Asuka Era (approximately sixth century AD), building techniques from the Asian continent were continuously being introduced in Japan along with construction rules and regulations that were integrated into a national system. ${ }^{74}$ From early modern times (seventeeth century), the previously monopolistic and relatively closed groups of craftsmen gradually disintegrated with the demand for new configurations of skills and labour when the lords began building castles. This shift highlighted the importance of organisation; the lords began to select and appoint, as leaders, craftsmen with genuine leadership skills, who by entering into master-servant relationships eventually became feudal technocrats. ${ }^{75}$

The social status of carpenters grew, while their knowledge system evolved significantly. A hallmark event was the emergence of kikujutsu and related publications from the beginning of seventeenth century to the end of the Shogunate Era (late nineteenth century). According to Naito Masa ${ }^{76}$ more than one hundred books about kikujutsu were published in this period. Kikujutsu is composed of the term guiju (kiku in Japanese), transmitted from China, and the term jutsu (術), method or technique; it now refers specifically to a drawing technique. In the Chinese context, the so-called guiju was an established custom among carpenters. In Japan,

Press, 2016).

${ }^{73}$ Liang Sicheng, ed., Yingzao fashi zhushi [Annotation of Yingzao fashi] (Hongkong: Joint Publishing, 2015), 20.

${ }^{74}$ From the Taika Era (645-650), Japan was ruled according to a legal Code that applied laws and regulations introduced from the Tang dynasty in China. One law (Engishiki), enacted in 967, listed the building regulations. In China, the Song dynasty (960-1279) inherited many of the laws from Tang dynasty including building-related regulations. Yingzao fashi can be seen as one application of these regulations. On the relation between Engishiki and Yingzao fashi, see Zhang Shiqing, "Gudai jianzhu shengchan de zhidu yu jishu-Song yingzaofayu yu riben mugongliaoshi de bijiao" [Building regulations and technology in ancient times- a comparative study on Yingzao Fashi in Song dynasty and Engishiki in Japan], Huazhong Architecture 10, no.3 (1992): 48-53.

75 Ota Hirotarou, Riben jianzhushi xushuo [Japanese architecture history] (Shanghai: Tongji Press, 2016), 159.

${ }^{76}$ Naito Masa, "Daiku gijyutsusyo ni tsuite" [About carpentry technique books], Kenchikushi kenkyu 30, 1961. 
however, after the transformation to kikujutsu, guiju referred to a method of drawing with a ruler or compass.

Japanese publishing traditions since the seventeenth century have seen a constant development of kikujutsu. The initial books on the subject merely included patterns (similar to certain illustrations in Yingzao fashi), but new knowledge was constantly introduced. Take Houen jundo (1788) as an example, where the carpenter and author Mizoguchi added information related to the earth, small aperture imaging, drawing of various geometric figures with compasses, drawing methods for vortex lines, etc. (Figure 6). This information originated partly from traditional East Asian mathematical knowledge and partly from Western knowledge. ${ }^{77}$ As the contents of these technical books expanded beyond purely practical guidance for carpenters, Japanese wasan (traditional mathematics) featured more prominently. This development reached its peak with the Shoya kujutsu youkai (Essentials of carpentry techniques, 1833), written by Heinochi Masaomi).

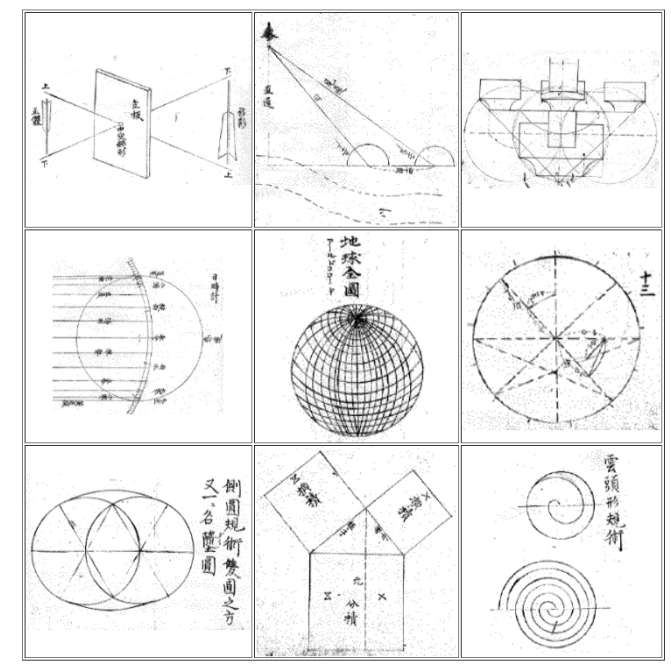

Figure 6. Illustrations from Houen jundo ([方円順度]1788). Public domain.

\begin{abstract}
77 Figure 6 illustrates how kikujutsu texts brought together mathematical knowledge from different traditions. There are topics which by then were classic in Chinese mathematics, including "Pinhole imaging" (top left) and Pythagoras' theorem (top centre), Western knowledge about the globe (centre) and Japanese traditional mathematical ways to draw an ellipse (bottom left) and a helical line (bottom right). Interestingly, there is also an illustration about how to draw a dougong with a compass (top right). The author never found such drawing technique applied to dougong making in China, nor in any historical materials, nor heard of it from experienced carpenters. In Chinese practice the curves of a dougong are made from line segments. On the history of mathematics in China and Japan, and the impact in each country of successive waves of hybridisation with Western mathematics, see Andrea Bréard and Annick Horiuchi, "History of Mathematics Education in East Asia in Premodern Times," in Handbook on the History of Mathematics Education, ed. Alexander Karp and Gert Schubring, 153-74 (New York, NY: Springer, 2014), doi: 10.1007/978-1-4614-9155-2_8.
\end{abstract}


Heinochi Masaomi was the tenth-generation descendant of a chief carpenter family. He was born into a wasan family and adopted into the carpenter family in his 20s. Architecture historian Sekino Masaru's description of his life revealed the changing process of his identity: "Heinochi did not understand architecture at first and was disparaged by the official chief carpenters. But he studied hard and even used up all his money. Finally, after 6 years, he was proficient in carpentry." 78 After Heinochi, kikujutsu truly became a method for using systematic geometric construction to present architectural details in three dimensions, achieving a kind of "objectification of craftsmanship." ${ }^{79}$ Kikujutsu continued to develop and spread through the late Shogunate Era, reaching its publishing peak in the second half of the nineteenth century ${ }^{80}$

Kikujutsu knowledge circulated among and was developed by craft practitioners. At the very moment it reached its peak, at the beginning of the Meiji Era in 1868, Western architectural technology was introduced to Japan top-down, with government support. During the transfer between old and new technologies, Japanese chief carpenters adapted kikujutsu and timber material to create buildings similar in style to Western structures. ${ }^{81}$ Although those buildings were seemingly Western in style, their internal structure and details were constructed with traditional craftsmanship.

After Western architecture took root in Japan, kikujutsu as a knowledge sphere became sealed within traditional architectural craftsmanship; nevertheless, it was still passed down without interruption. Although it lost its leading status, it still played a role in repairing traditional ancient buildings and civil buildings as a traditional construction technology. In today's vocational carpentry schools in Japan, kikujutsu is still a discipline, ${ }^{82}$ and the improved ruler with special scales for kikujutsu practise is still the most common and popular tool for

\footnotetext{
${ }^{78}$ Nakatani Norihito, Kinsei kenchiku ronsyuu [Pre-modern architectural theory] (Osaka: Acetate, 2005), 24.

79 Ibid., 23.

${ }^{80}$ Ibid., 126.

${ }^{81}$ Japanese architectural historians call the buildings that resemble Western style but rely on traditional carpenters' techniques giyofu architecture, literally "Western imitation style." It flourished during the early Meiji period, then disappeared as knowledge of Western construction techniques became more widespread. One of the famous carpenters who took charge of some large-scale public giyofu buildings was Shimizu Kisuge, the founder of Shimizu corporation. After a series of successful giyofu projects in Tokyo, he became a model, with carpenters from all over Japan coming to visit his works and learn from him. See Fujimori, Nihon no kindai kenchiku, 88-115.

${ }^{82}$ Taniguchi Yuji, "Dentou kenchiku no waza wo tooshite ginou no genntenn ni kaeru-Shimane kenritsu matsue koutou gijyutsu kou, dentou kenchikuka wo haikenshite" [Return to the starting point of building technique through traditional skills: a survey of the Traditional Building Department of Matsue Technical School in Shimane prefecture], Sangyo kyouikugaku kenkyu [Study of industrial education] 34, no.1 (2004): 93-4.
} 
woodworking. In 1993 kikujutsu techniques were declared a tangible cultural property, part of the national cultural heritage. ${ }^{83}$

\section{Conclusions}

Though brief, this survey has revealed some notable contrasts and similarities between China and Japan. The similarities are visible in the integration of the Western architectural discipline; the most striking contrasts are in the impact of this modernisation process on the status and transmission of indigenous building skills and knowledge. Western architecture was introduced to China via Chinese scholars educated in USA. While Meiji government actively invited Western architects to build and teach in Japan. In both countries, trained architects later sought to increase the discursive power of their field by applying its criteria to write the architectural history of their own civilisation. In both cases, they sought heritage roots in the oldest and most prestigious buildings, notably temples, developing formalist criteria for establishing a stylistic chronology, and paying little heed either to the craft techniques of building or to the linkages between public and vernacular building traditions. As for traditional building skills, following the modernisation of the architecture industry, some traditional carpenters, of whom Pan Dehua and Nishioka Tsunekazu are outstanding representatives, survived by repairing and reconstructing local iconic ancient relics; they responded actively but very differently to the challenges of modernisation, developing a new era of knowledge making suited to the emerging heritage industry. However, the Japanese carpenter erected several iconic buildings falling back on transmitted carpentry knowledge. Having proved his expertise he was able to convince even highly respected scholars that empirical knowledge must be accepted. The Chinese carpenter realized the design of a scholar. Although Liang Sicheng has won a lot of empirical knowledge, he was no carpenter. Therefore he could never see details only a craftsman can detect (e.g., traces of yariganna). In the end Pan Dehua had to execute what he was told to do. Meanwhile, in some marginal areas that have not yet been modernised, traditional building practices and knowledge are still passed down locally, while the craft knowledge inscribed in kikujutsu publications and $L u$ Ban jing has gained a new lease of life in the heritage era. ${ }^{84}$

Other key differences between China and Japan are rooted in their pre-modern social structures and how they translated into the modern era, with the greatest difference here being the social

\footnotetext{
${ }^{83}$ See the online database of Japanese heritage: https://kunishitei.bunka.go.jp/bsys/searchlist.

${ }^{84}$ Carpentry technique has started to attract increasing attention in China as a form of intangible heritage since 2000. As an iconic event, the craft to build woven timber bridge in Zhejiang and Fujian was memorialized in a 2009 UNESCO Intangible Cultural Heritage designation. This effort has led to the significant training received by younger-generation carpenters who have constructed dozens of traditional timber bridges across the region. In architecture academic circles, wood has also been increasingly studied and discussed for application as modern construction material. These present a future when traditional carpentry knowledge would be examined and exercised.
} 
status of carpenters. The traditional Chinese social hierarchy of "scholar, farmer, artisan and merchant" led to the low social status of carpenters in imperial culture, with building activities classed as craft and commerce rather than a high-status art. There is little historical evidence of dialogue between carpenters and the state officials who directed public building projects, or with the gentry who employed local carpenters to build their houses. This segregation of skilled knowledge is echoed in today's heritage culture. The carpenter Pan Dehua was able to parlay his craft skills into the authorship of a monograph on the dougong bracket set, but in tracing the history of this now iconic feature he simply reinforced the orthodox narrative set out by architectural historians, rather than testing its assumptions through his craft experience as Nishioka Tsunekazu did for the history of Horyuji. In Japan, as early as the seventeenth century the carpenters attached to various lords had gained social status as technocrats. ${ }^{85}$ The diffusion of building technology knowledge driven by the introduction of geometric knowledge had contributed significantly to the standardization of building technology, which in turn supported those chief carpenters/technocrats in supervising the constructions in a more efficient way. ${ }^{86}$ It can be seen that the accumulation of knowledge in kikujutsu publications throughout the seventeenth century to modern times along with the building technology became increasingly socialized. ${ }^{87}$

The modern era brought new opportunities for traditional carpenters to work across boundaries. Nishioka made himself an admired cultural authority and was able to obtain abundant resources in various fields. His project of restoring yarigana was supported by academics and by fellow craftsmen in different fields. His collaborator Mizuno is a famous Japanese sword-maker, and as a high-end collectable item, the Japanese sword has circulated along with the Japanese warrior culture across the world. Collaborating with a well-known sword-maker made it easy for Nishioka to commercialise his woodworking tools as high-end products. But there has been no similar high-end commercialisation of carpentry skills as heritage in China, where as the example of Pan Dehua shows, carpenters who hope to change their social identity and continue their job through intangible heritage must still rely on the mainstream national narrative of the architectural elite.

\footnotetext{
${ }^{85}$ The author studied the construction innovation of a timber bridge built in 1673, Japan. The case study showed collaboration with the chief carpenter and the lord who he served. Without the help from the latter, the carpenter wouldn't have had the access to learn from other bridge design inspirations. The bridge was built out of military purpose to protect the lord's castle at that time. See Ren Congcong, "A timber bridge constructed in seventeenth-century Japan: Study of innovation in the construction of Kintai bridge and its maintenance techniques," in Building Knowledge, Constructing Histories, ed. Byine Wouters, Stephanie Voorde, Inge Bertels, Bernard Espion, Krista Jonge and Denis Zastavni , 1113-20 (Brussels: CRC Press, 2018), on 1114-5.

${ }^{86}$ Nakatani, Kinsei kenchiku ronsyuu, 26-7.

${ }^{87}$ Ibid., 126.
} 


\section{Acknowledgements}

This work is supported by National Natural Science Foundation of China. Project number: 51908543. I thank Prof. Francesca Bray, Prof. Greg Clancey and Prof. Annapurna Mamidipudi for enlightening discussions.

\section{Competing interests}

The author has declared that no competing interests exist.

\section{Funding}

National Natural Science Foundation of China. Project number: 51908543. 